WSRC-RP--92-115

DE92 010987

\title{
SUMMARY OF ALUMINUM NITRATE TESTS AT THE F/H-ETF (U)
}

by

D. J. McCabe and A. W. Wiggins

Westinghouse Savannah River Company

Savannah River Site

Aiken, South Carolina 29808

This is a Technical Report

\section{DISCLAIMER}

\begin{abstract}
This report was prepared as an account of work sponsored by an agency of the United States This report was prepared as an account of work sponsored any agency thereof, nor any of their Government. Neither the United States Governor implied, or assumes any legal liability or responsiemployees, makes any warranty, express or implied, or assu information, apparatus, product, or bility for the accuracy, completeness, or usefulness of any information, apparalus, product, or process disclosed, or represents that its use would not infringe privately owned rade name, trademark, ence herein to any specific commercial product, process, or ser imply its endorsement, recommanufacturer, or otherwise does not necessarily constitute or imply its endorefor. The views mendation, or favoring by the United States Government or any agency thereof those of the and opinions of authors expressed herein do not
\end{abstract}

This report was prepared in connection with work done under Contract No. DE-AC09-89SR18035 with the U.S. Department of Energy. By acceptance of this report, the publisher and/or recipient acknowledges the U.S. Government's right to retain a nonexclusive, royalty-free license in and to any copyright covering this report, along with the right to reproduce and to authorize others to reproduce all or part of the copyrighted report.

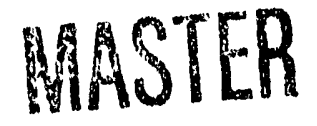


January 20, 1992

TO: W. Payne, 742-A
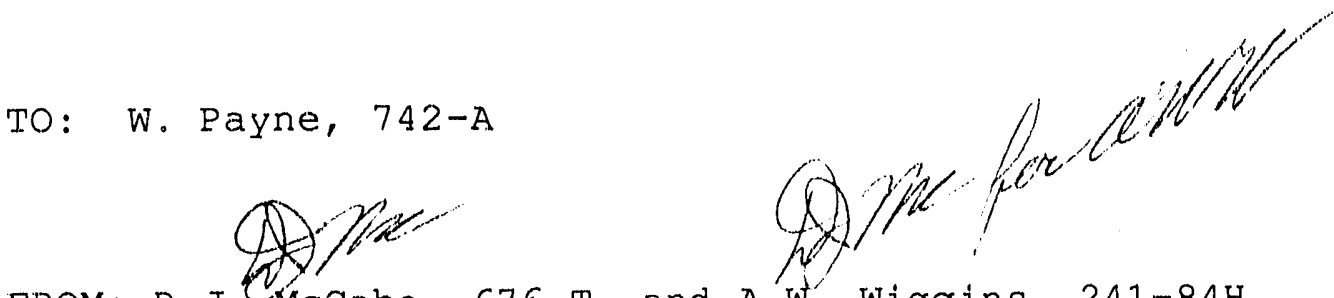

FROM: D.J.MCCabe, 67€-T, and A.W'. Wiggins, 241-84H

SUMMARY OF AJUMINUM NITRATE TESTS AT THE F/H-ETF (U)

Attached is the report on aluminum nitrate testing at the $\mathrm{F} / \mathrm{H}$ Effluent Treatment Facility which SCDHEC required when approval for the testing was granted.

AWW : aww

CC: G.T. Wright, 703-H

R.W. Harral, 703-H

S.S. Cathey, 703-H

W.L. Tamosaitis, 773-A

I.K. Sullivan, $241-84 \mathrm{H}$

D.L. Fish, 773-A

S.T. Wach, 703-H

K.S. Wierzbicki, 703-H

K. Uzochukwu, 703-H

M.R. Poirier, 676-T

J.I. Siler, 676-T

WMT File 401.9.3, 703-H File Room

SRL Records ( 4 copies) 
CONTENTS

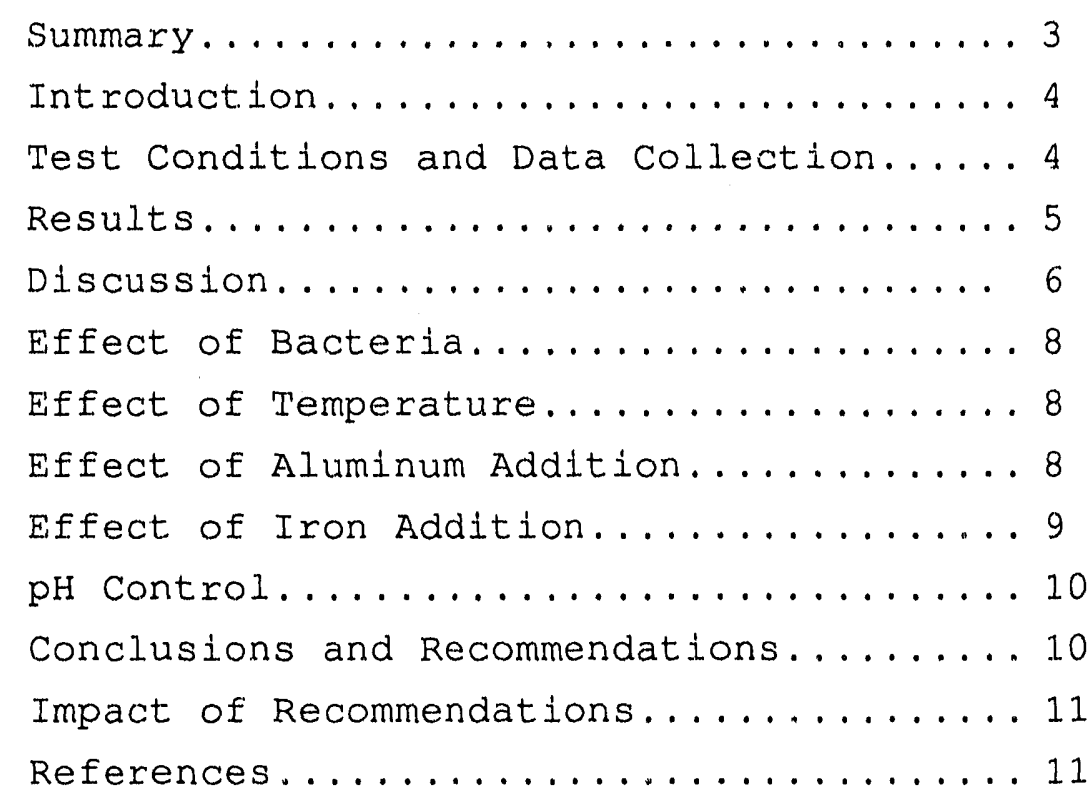

IIST OF TABLES

1. Summary of ANN Tests............13

2. AnN Test $\# 1 \ldots \ldots \ldots \ldots \ldots \ldots \ldots \ldots$

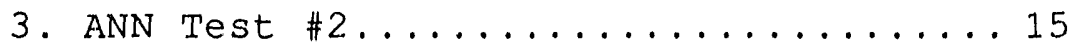

4. ANN Test $\# 3 \ldots \ldots \ldots \ldots \ldots \ldots \ldots \ldots \ldots$

5. ANN Test $\# 4 \ldots \ldots \ldots \ldots \ldots \ldots \ldots \ldots$

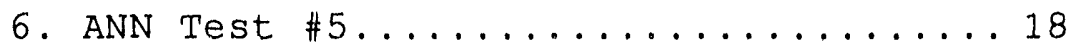

7. ANN Test $\# 6 \ldots \ldots \ldots \ldots \ldots \ldots \ldots \ldots$

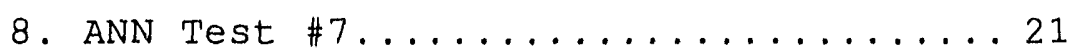

LIST OF FIGUFES

1. ANN Test $\# 1 \ldots \ldots \ldots \ldots \ldots \ldots \ldots \ldots$

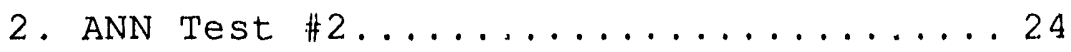

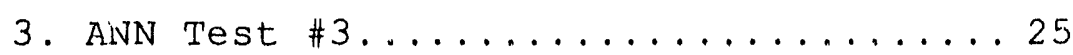

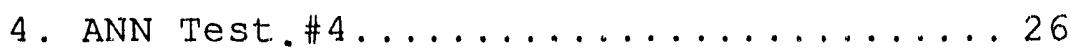

5. ANN Test $\# 5 \ldots \ldots \ldots \ldots \ldots \ldots \ldots \ldots \ldots \ldots$

6. ANN Test $\# 6 \ldots \ldots \ldots \ldots \ldots \ldots \ldots \ldots \ldots 28$

7. ANN Test $\# 7 \ldots \ldots \ldots \ldots \ldots \ldots \ldots \ldots \ldots$

8. ANN Test \#7, Normalized......... 30 
SUMMARY OF ALUMINUM NITRATE TESTS AT THE F/H-ETF (U)

\author{
D.J. McCabe and A.W. Wiggins
}

\title{
SUMMARY
}

Biofouling of the Norton ceramic filters in the F/H Effluent Treatment Facility (ETF) has been minimized by bacterial control. strategies on the influent streams. However, enough bacteria still exists in the routine influent to impact the filter performance. One method of remediating biofouling in routine influent, initially observed in laboratory tests on simulant solutions, involves addition of aluminum nitrate to the influent wastewater. Tests on actual feed at the ETF using aluminum nitrate (ANN) showed significantly improved performance, with increases in filter permeability of up to four-fold compared to the baseline case. These improvements were only realized after modifications to the $\mathrm{pH}$ adjustment system were completed which minimized upsets in the $\mathrm{pH}$ of the feed solutions.

Non-routine influent streams cause severe fouling of the filters, reducing the filter permeability by $>80 \%$ in less than 2 hours. These nonroutine streams consist primarily of storm water collected in large retention basins. The ability of the ETF to treat this wastewatex, in the event of a basin contamination, is critical to achieving the mission of the ETF. Laboratory tests on both simulated and actual nonroutine wastewater indicated that pretreatment with both ANN and iron(III) nitrate dramatically improves the filterability of this waste. This result was confirmed in one test at the ETF, suggesting that ANN and iron(III) nitrate addition will significantly improve the ability of the ETF to process these waste streams.

ETF testing of aluminum nitrate addition has successfully demonstrated the benefits in filter performance of this pretreatment method. Based on the results of these tests, it is recommended that a permanent change in the operating permit for the ETF be requested from SCDHEC to allow the addition of ANN and iron(III) nitrate to the influent on a routine basis. The discharge water quality is not adversely affected, and the capacity of the ETF is greatly increased. Approval would enable operations to continue chemical additions using temporary facilities until more permanent facilities could be designed and constructed. The long term plan will be to add a permanent tank and piping to facilitate addition of the chemicals to the wastewater collection tanks (WWCT). 


\section{INTRODUCTION}

SRI studies conducted on simulated F/H-ETF wastewater indicated that filter performance could be improved by the addition of aluminum nitrate $(1,2)$. The studies concluded that the simulant must be $\mathrm{pH}<2.7$ prior to addition of aluminum nitrate and subsequent neutralization. This procedure improved the filterability of simulant solutions containing high concentrations of bacteria ( 1. OE 7 bacteria/mI). Additionally, it was noted that the filter was more readily cleaned after this experiment ( $1 . e$. , the "memory effect" was not observed. This "memory effect" refers to the observation that filters that are exposed to water with high bacterla levels do not return to the original permeability after cleaning). The recommendation was subsequently made to the ETF to attempt to use aluminum nitrate on the routine $\mathrm{F} / \mathrm{H}-\mathrm{ETE}$ influent to increase filter performance.

Simulant solutions which mimicked performance of nonroutine retention basin water were also developed (3). SRL discovered that the filterability of simulant solutions could be increased using a mixture of iron and aluminum nitrates (4). Laboratory scale testing on water from one of the storm water retention basins indicated that this pretreatment technique significantly improved filterability (5). Concentrations of the iron and aluminum salts necessary to optimize performance on retention basin water were also determined (6).

A total of seven tests were conducted from November 1990 to December 1991 at the F/H-ETF using aluminum nitrate. The final test (Test \#7) included the addition of both iron and aluminum nitrate to water from the $281-8 \mathrm{H}$ storm water retention basin. Table 1 shows a summary of the tests and lists the wastewater source, bacteria density, aluminum concentration, $\mathrm{pH}$, iron concentration (test \#7), and flow rate improvements observed.

\section{TEST CONDITIONS AND DATA COLLECTION}

The aluminum nitrate tests were conducted by first adding approximately 130,000 gallons of the desired influent to one of the wastewater collection tanks (WWCT). The WWCT was then isolated from any sources of additional influent for the duration of the test. In all tests, filter performance on the raw influent was first established as a baseline for comparison. Sufficient nitric acid ( 64 wto $)$ was added to drop the $\mathrm{pH}$ to below 2.7 , and the tank contents were recirculated for at least 12 hours to ensure thorough mixing. During tests 6 and 7 , a second baseline flow rate was established after the addition of nitric acid. Aluminum nitrate nonahydrate (ANN) solution (60 wt. of) was added and the tank recirculated an additional 12 hours or more. The filter(s) used for the baseline case was then used in the test runs. In test \#3, the other two filters were also used in the test runs. In test \#7, a solution of iron(III) nitrate was subsequently added to the WWCT after the ANN filter run and the same filter was run again to test for any further filter improvement. 
Flow rates and pressures were manually recorded at appropriate intervals during each run. These values were collected only on Stage 1 of each filter, since it is the only stage with pressure indicators on both the feed and concentrate lines. Corrections were made for transmembrane pressure fluctuations due to

1) actual inttial pressures which varied from the setpoint, 2) reductions in the permeate pressure during the run to maintain a more constant flow throughout the ETF, and 3) the presence of an orifice in the stage 1 filter feed line of filter train \#1. This allowed calculation of pressure-corrected flow rates which are used to compare the different filter runs.

Calculated Stage 1 permeablitties (in GPM/psi) are given in Tables 2 - 8. It was assumed that the flow rate is linear with respect to pressure in the ranges used here. It has been shown that this relationship holds for clean filters, but fouled filters will have a slightly lower flux as pressures increase due to the compaction of the fouling layer of precipitates. The higher solids loading in stages 2 and 3 caused only negligible permeability differences between stages on tests $3-7$.

Bacteria densities were measured in the filter feed solutions using the Acridine Orange Direct Count (AODC) technique by T.C. Hazen of Savannah River Laboratory. Averages of the sample results for each test are shown in Table 1.

\section{RESUI,TS}

Calculated flow rates which are pressure-corrected to 30 psi of transmembrane pressure are shown in Eigures 1-7. All flow rates refer to the permeate flow rate at constant pressure. The actual flow rates were generally higher due to operation of the filters with 40 psi of transmembrane pressure. Table 1 contains a summary of the test conditions and the resulting flux improvement observed. The initial and final total feed flow rate and all of the parameters measured are shown in Tables 2-8. Summaries of the individual tests are presented below, with a description of the results.

\section{Test \#1}

The aluminum concentration in ETF test \#1. was measured to range between 49.3 and $134.9 \mathrm{mg} / \mathrm{L}$ (Figure 1). The flow rate of the third stage of the filters, which has the highest solids concentrations, dropped dramatically between backpulses. was apparently caused by the high solids loading. Large pH fluctuations were observed, particularly in F3 run \#1 and F1 run \#2 (F3 is Filter train \#3).

\section{Test \#2}

Significant improvements in filter flow rate were not observed in test \#2 (Figure 2). Minor fluctuations in $\mathrm{pH}$ were observed during startup of both filter runs. In filter \#3, the filter flow rate was maintained at approximately the same level as the baseline run until an upset in the $\mathrm{pH}$ of the feed solution occurred after approximately 6 hours online. 


\section{Test \#3}

Significant improvements in the filter flow rate were observed in Test \#3 (Figure 3). The initial flow rates were higher after the addition of ANN, and higher flow rates were maintained during the runs. When pH upsets occurred, the filter flux dropped dramatically. The apparent recovery in flow rate after the upset was only temporary.

\section{Test \#4}

Initial flow rates for the ANN runs were not significantly higher than on the baseline run; however, the flow was maintained at a much higher level (Figure 4). After cleaning, Filter \#2 had higher initial flow rates and maintained a high rate for the duration of the experiment.

\section{Test \#5}

The baseline run and ANN runs were quite similar to one another for test \#5 (Figure 5). An increase of 20 GPM was observed for the ANN run on filter \#1. The aluminum concentration during the baseline runs was higher than expected $(5.3 \mathrm{ppm})$ due to the wwct heel from Test \#4.

\section{Test \#6}

Dramatic improvements in filter performance were observed in Test \#6 (Figure 6). With no pretreatment, the ETF sump water, which is notoriously difficult to filter, yielded an $80 \%$ flux loss within two hours of operation. Addition of acid increased the filter performance slightly, and the iron content increased also. Addition of ANN tripled the flow rate through the filter. After cleaning Filter \#3, further improvement in filter performance was observed.

\section{Test \#7}

Retention basin wastewater severely fouled the Norton filters, even though the bacteria densities were intermediate (2.0E6 bacteria/mL). Addition of acid increased filter performance slightly. The addition of ANN dramatically increased filter performance, until a pH upset occurred. The subsequent addition of iron(III) nitrate showed slightly higher filter performance.

\section{DISCUSSION}

\section{Test \#1}

The quantity of aluminum hydroxide used in test \#1 exceeded the capacity of the filters. The optimum level of aluminum had been determined from laboratory tests on a single-lumen filter to be $>50 \mathrm{mg} / \mathrm{L}$, but the poor performance of the filters during this test (Figure 1) was attributed to overloading the filters. The aluminum nitrate concentration was reduced in subsequent runs to avold overloading the filters. Upsets in the feed pH contributed to the poor filter performance observed. 


\section{Test \#2}

It appears that the increased quantity and type cf solids (1.e. aluminum hydroxide) caused the fouling during $\mathrm{pH}$ upsets to be more pronounced than in previous runs. Recommendations for improving $\mathrm{pH}$ control included diluting the caustic day-tank solution, tuning of the controllers on the two pH adjustment tanks, vigilant maintenance of continuous flow rates during startup, and damping of the surges in influent flow rate by decreasing the gain on the automatic tank-level controller. These recommendations were implemented prior to ANN Test \#3.

\section{Test \#3}

Significant improvements in filter performance were observed after ANN addition, although the use of cleaner filters may have partially contributed to the observed increase in flow rate. The initial flow rate on filter \#2 increased after the cleaning cycle, supporting the observation that the filters are easier to clean when ANN is used. However, pH upsets continued to severely impact the filter performance, further improvements in pH control. were implemented. Agitation of the caustic daytank during make-up of the dilute caustic solution was begun in an attempt to decrease the magnitude of $\mathrm{pH}$ upsets. Before Test \#4, operators were instructed to implement the existing procedure for an emergency manual shut-down of the filter if the pH exceeds the range of $7.5 \pm 1.5 \mathrm{pH}$ units.

\section{T'est \#4}

The addition of ANN to the influent wastewater was shown to be highly beneficial to the fliter performance. The filters exhibit higher initial flow rate after the cleaning cycles. The pH upset controls which had been implemented were concluded to be adequate for further testing.

\section{Test \#5}

The water used in the baseline contained a high aluminum concentration from the heel remaining in the wastewater collection tank after Test \#4. This quantity of aluminum was apparently sufficient to improve the filter performance to such an extent that only a small increase in performance was observed after additional ANN was added.

\section{Test \#6}

The ETF sump water used in Test \#6 was collected in the wastewater collection tank over a period of several weeks. Significant bacterial growth occurred during this time, yielding a bacteria count of over $9.0 \mathrm{E} 8 \mathrm{ce} 1 \mathrm{ls} / \mathrm{mL}$. After acid addition the bacterta density dropped dramatically, probably due to lysing of the bacterial cells. Laboratory tests have shown that lysed bacteria cells foul the filters as quickly as intact celis, so this would not account for the increased performance after acid addition. The amount of iron in the feed solution increased after acid addition and could have contributed to the improved 
performance. The source of tron is probably precipitated material in the bottom of the wastewater collection tank which dissolved upon actd addition, or could have been an impurtty in the acid. The large improvement in filter performance in this test is attributed to the ANN addition and maintenance of a steady $\mathrm{pH}$ during the test runs.

\section{Test \#7}

The filtration of retention basin water has caused the most severe fouling of any wastewater observed thus far. The addition of ANN increased the filter flow rate to 60 GPM (after one hour online). Subsequent addition of iron nitrate increased the performance only about 5 GPM above that observed with ANN. The quantity of ANN added was significantly higher than that which had been recommended from the laboratory tests. Further studies with different ratios of iron and aluminum are needed to determine the relative magnitude of the benefits.

\section{Effect of Bacteria}

The fouling due to low concentration of bacteria $(<9.00 E+04$ bacteria/mL) has been shown to have a negligible influence on filter performance. Based on prior studies, intermediate fllter performance (40 - 75 GPM/filter) would be expected when processing wastewater colicaining $1.0 \mathrm{E}+05$ to $1.0 \mathrm{E}+06$ bacteria/mL. For bacteria levels $>1.0 \mathrm{E}+06$ bacterla/mL, performance of the filters drops dramatically. Baseline performance tests in \#6 and \#7 showing $>80 \%$ flux loss in two hours, tllustrating the dramatic effect that biological material can have on performance of the filter system. This is the type of water where use of ANN shows the greatest improvement in filter performance. The wastewater used in Test \#7 is expected to also contain other blological debris such as algae, as well as colloldal clay particles.

\section{Effect of Temperature}

It is possible that the lower flow rate observed during some of the runs is partially due to the low temperature of the wastewater (as low as $14^{\circ} \mathrm{C}$ ). The calculated flow rates were not corrected for temperature variations. It has been shown that the temperature dependence on the clean water permeability of these ceramic filters is approximately $1.7 \%$ /degree C. This was particularly signiflcant in Test \#7, which was run during cold weather in December.

\section{Effect of Aluminum Addition}

It is apparent that the permeability of the Norton filters improved after ANN addition, compared to the baseline, in tests 3-7. The lower permeabilities observed in T'ests 1 and 2 have been attributed to overloading the filter with solids and pH upsets. The higher permeabilities observed with the aluminum nitrate could be partially attributed to the higher initial flow rates due to usin' cleaner filters. Improved initial flux was also observed in laboratory experiments with simulant solutions containing ANN. The higher initial flow rates are attributed to 
an imp fovement in the cleaning cycle effectiveness. Significant differences in initial flow rates are often seen during norma.l operation. Improvement in the initial flow rate for the ANN runs versus the baseline can be seen in most cases. Only in Tests 2 and 5 is this improvement not observed, where the presence of a higher than normal level of aluminum in the raw wastewater probably minimized the improvements due to added ANN. The source of aluminum has been attributed to the residual tank heel in the WWCT from previous tests.

Based upon laboratory observations, the use of aluminum nitrate is not: expected to have a large impact on wastewater containing Low densities of bacteria. The benefit from aluminum nitrate is expectied to be found in the processing of wastewater containing moderate-to-high concentrations of bacteria. In this case, the precipitated aluminum hydroxide probably both absorbs onto the bacteria and acts as a pre-coat on the filter. The bacterial debris is unable to adhere to the fllter, making subsequent cleaning easier. These observations were conflrmed during the ETE tests. Tests with low bacteria density wastewater showed only a 1 to 2-fold improvement with ANN addition. Tests 6 \& 7 showed 3 to 4-fold improvement. Overall, the flux for the ANN runs showed less dependence on bacteria concentration when compared to the baseline runs.

No effect on the ETF effluent to outfall H-016 was detected during the testing. The NPDES samples on treated water measured $<0.050 \mathrm{mg} / \mathrm{L}$ of aluminum, which is the same level detected during non-test periods. An analysis of filter permeate during Test \#1 indicated $0.3 \mathrm{mg} / \mathrm{L}$ of aluminum, whlle the fllter feed solution was up to $135 \mathrm{mg} / \mathrm{L}$. As expected, the added aluminum is riearly al1 removed by the filtration system, and the remainder is removed by the reverse osmosis system.

\section{Effect of Iron Addition}

Test \#7 examined the observation from laboratory tests where iron nitrate and aluminum nitrate act synergistically to improve filter performance on retention basin water. Based on the performance of the filter during the ETF test, it appears that the addition of iron resulted in only a modest increase in performance. Inwever, this benefit may be partially due to the higher initial flow rate which is due to easier cleaning when using ANN. (The iron and aluminum test was conducted on a filter after an ANN run.) The normalized $f l u x$ (J/Jo) data for Test \#7 are shown in Figure 8. Normalization of the data eliminates the variability of the initial flow rates and allows direct comparison of the runs. It appears from Figure 8 that the rate of fouling is virtually identical for the runs before and after Iron addition. Therefore, the synergistic benefit of iron addition has not been fully demonstrated, perhaps due to the ratios of iron and aluminum which were used. More testing is required before the effect of this interaction can be quantified. 
The sensitive dependence of filterabilty on the $\mathrm{pH}$ of the wastewater containing ANN was observed early in the testing. Substantial effects on the fllter permeablitty were observed which were due to pH excursions on the filter runs, as shown most clearly in Flgure 3 . Some recovery of the permeablitty occurred after the event, but this normally could not be malntained. The $\mathrm{pH}$ upsets were caused by the batching of the caustic day tank or, in some cases, by large varlations in the flow rate into the $\mathrm{pH}$ adjustment system. Batching of the caustic day tank involves addition of concentrated caustic and subsequent dilution. The caustic concentration in the tank changes rapidly, causing $\mathrm{pH}$ adjustment problems in the fllter feed system. The day tank was batched more frequently during some tests ( $1 . e$. Test \#3) because of the extremely low $\mathrm{pH}$ of the wastewater and somewhat due to the increased amount of aluminum(III) ion. It is expected that pH upsets result in formation of smaller, more gelatinous precipitates which foul the filter more rapidly.

The initial testing of aluminum nitrate ldentified problems with maintenance of the $\mathrm{pH}$ control and subsequently the fliter flow rates. Several changes were implemented to correct this. The concentration of sodium hydroxide in the caustic day tank was reduced from $7-8$ wt. concentration. The dilution of the caustic day tank produced significant improvements in the ability to maintain a stable $\mathrm{pH}$ during operation in Test \#3. This stable pH then contributad to the improvement in filter performance. Unfortunately, this dilution also led to more frequent batching of the caustic day tank, and thus contributed to the problems revealed in Test \#3.

After test \#3, further pH controls were made to lessen the effect of $\mathrm{pH}$ upsets during the ANN tests. The $\mathrm{pH}$ of the WWCT was kept above 2.0 (except for Test \#6 where it was 1.7 ). This resulted in less severe fluctuations in $\mathrm{pH}$ and fewer upsets. Also, the control room operators were instructed to shutdown the filter immediately if a low pH alarm was received. The low pH alarm is set at 6.0 and the holdup volume in the filter feed tank $(\sim 1000$ gallons) allows time for the operator to react to the alarm before the water reaches the filter. The $\mathrm{pH}$ would then be allowed to return to the control setpoint and the filter restarted. Further improvements are planned, which include changes to the caustic day tank operation by adding the caustic and water simultaneously, at the proper ratio, to eliminate the problem with the initial high caustic concentration in the tank during make-up.

\section{CONCLUSIONS AND RECOMMENDATIONS}

The greatest benefits of using aluminum nitrate are in the mitigation of fouling due to moderate-to-high concentrations of bacteria and in the improvement of the cleaning cycle efficiency. The detrimental effect of $\mathrm{pH}$ upsets have been lessened through the improvements already implemented. Planned improvements and operator diligence should virtually eliminate this problem in the future. Although severe bacterial fouling may not be completely 
remediated by the addition of aluminum nitrate, it is evident that filter performance can be greatly improved. This is especially true for non-routine influent stream which currently cannot be processed at the ETF due to severe filter fouling.

Testing of the synergistic behavior of aluminum nitrate and iron(III) nitrate $1 s$ not yet conclusive. Seasonal effects in the basins should be examined to determine if ANN/1ron(III) nitrate is effective for all cases. Therefore, it 1 s recommended that the addition of ANN and iron(III) nitrate be studied further at the E/H-ETF after provisions for these recommendations are completed. The effect of added aluminum nitrate on the filterability of wastewater containing higher concentrations of bacterta (i.e. ETF outside sumps) also warrants further testing.

It would be highly beneficial to the mission of the ETF to continue using ANN and iron(III) nitrate both for test purposes and for normal operation on an "as-needed" basis. Addition of the chemicals to the WWCT could be continued in the same fashion as during the testing phase until. more permanent equipment could be designed and installed. The ANN solution is added from a portable tank which is stored within the ETF Organic Removal area so that any leaks or spills will drain into the area sump. The ANN solution is pumped to the WWCT using the existing carbon bed dewatering pump (this pump is only needed ronce per year). The iron(III) nitrate is first dissolved in water in a 55-galion drum and pumped to the WWCT. All additions would be noted in the operating logbook.

\section{IMPACT OF RECOMMENDATIONS}

The SRI and ETF tests have shown that the target concentrations for aluminum and iron are $5-20 \mathrm{mg} / \mathrm{L}$ for aluminum and $10-20 \mathrm{mg} / \mathrm{I}$ for iron. Additions at these levels will result in a minimal increase in waste concentrate to Tank 50/Z-area ( 1000 gallons of additional waste concentrate per 1,000,000 gallons of wastewater), while not affecting the quality of the effluent to outfall H-016.

\section{REFERENCES}

1. WSRC-RP-90-562, "Improving Ceramic Microfilter Performance at the F/H-ETF via Aluminum Nitrate Addition" J.L. Siler, June 9, 1990.

2. WSRC-RP-90-566, "Improvement in the Filtration of Bacteria-Containing Simulants by the Addition of High Levels of Aluminum (III) Nitrate (U)"

D.J. McCabe and M.R. Poirier, June 1.1, 1990.

3. WSRC-RP-91-851, "Adverse Effects of Lipopolysaccharides on Norton Ceraflow Ceramic Filters (U)"

D.J. McCabe and M.R. Poirter, August 1, 1991

4. WSRC-RP-01-1107, "Remediation of the Effects of Lipopolysaccharides on Norton Ceraflo'T Ceramic filters (U) "

D.J. McCabe and M.R. Poirier, October 29, 1991 
5. WSRC-RP-91-954, "Filtration of Pretreated Retention Basin Water with the Norton Filters (U)"

M.R. Poirier and D.J. McCabe, september 25, 1991

6. WSRC-RP-91-1188, "Optimization of Norton Filter Performance on Retention Basin Water with Iron and Aluminum Addition (U) "

D.J. McCabe and M.R. Poirier, November 26, 1991 


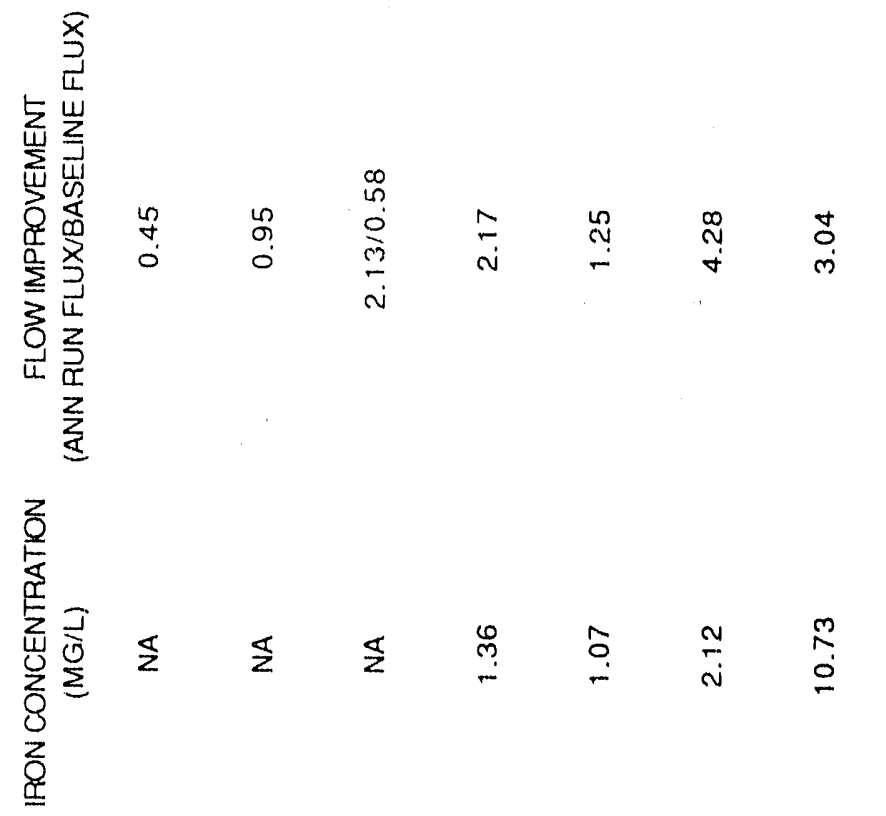

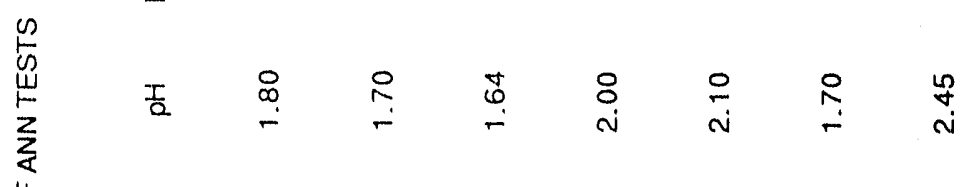

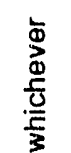

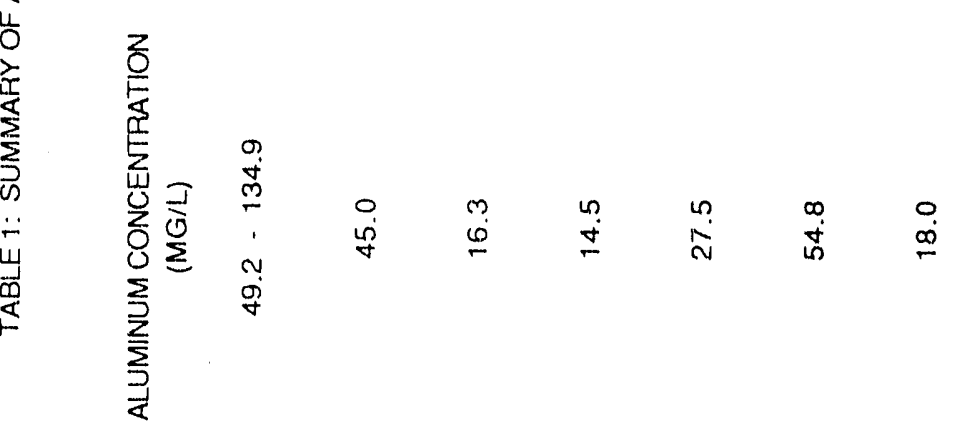

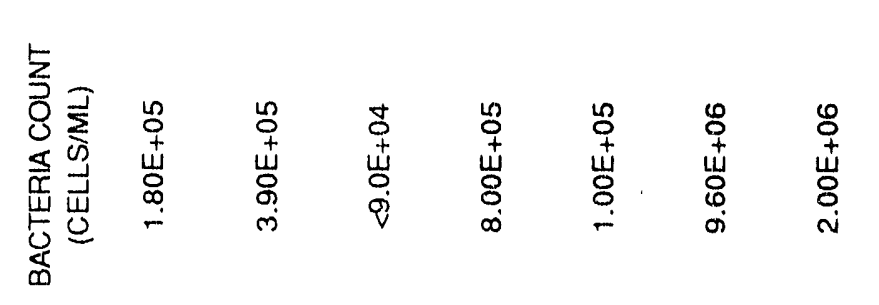

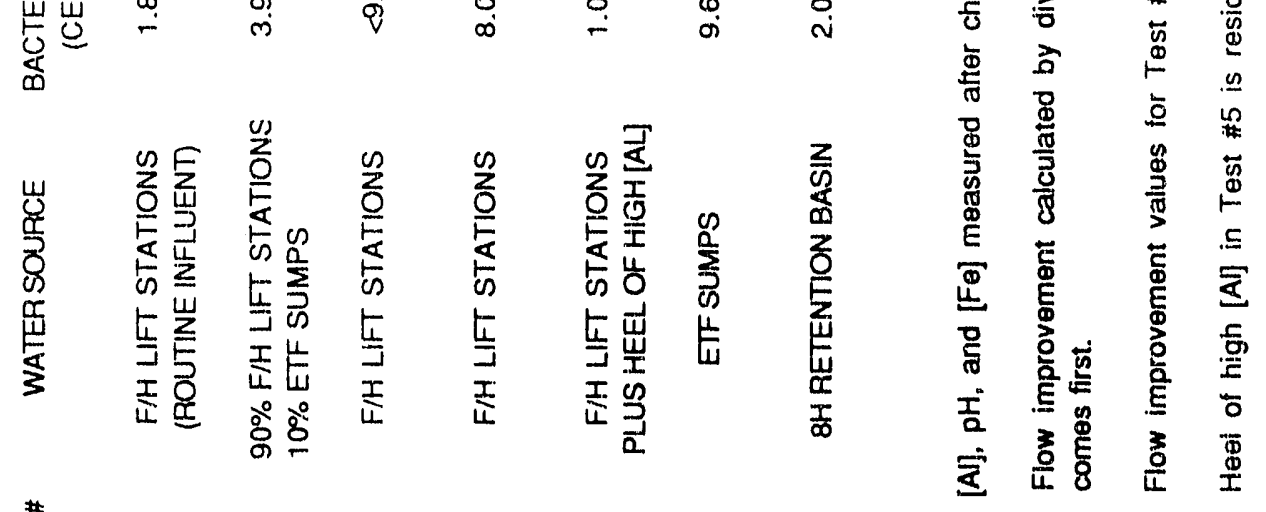

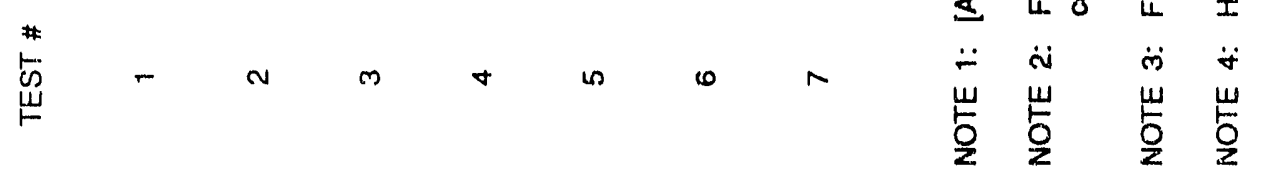




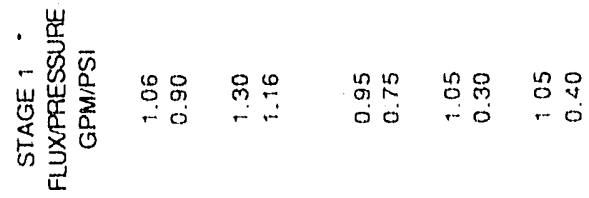

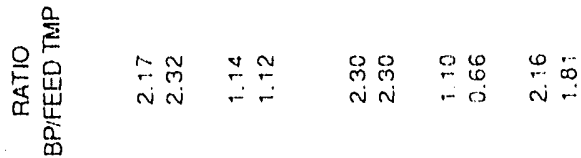

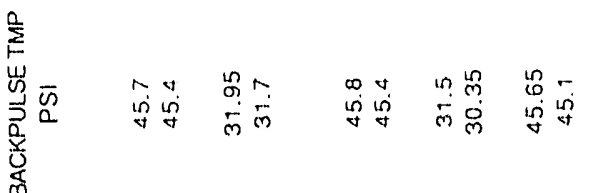

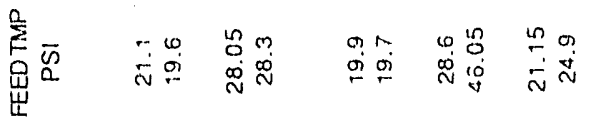

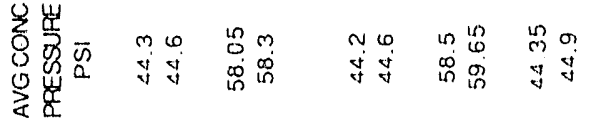

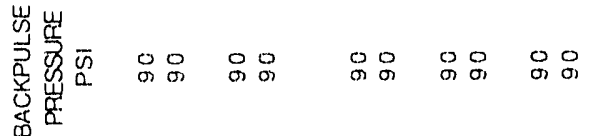

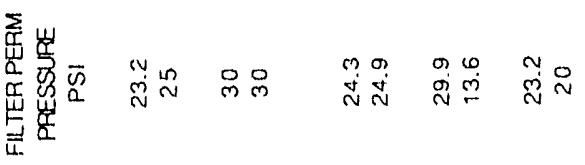

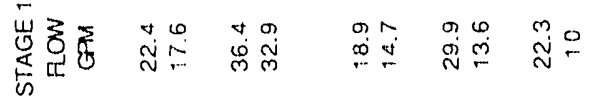

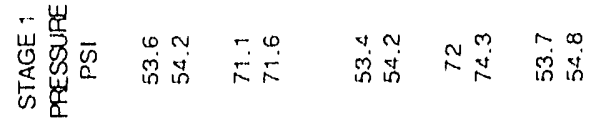

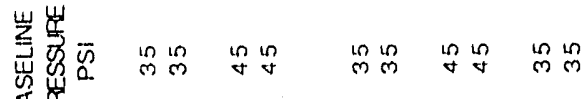
娄

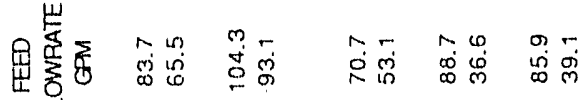
设 
·宸岛

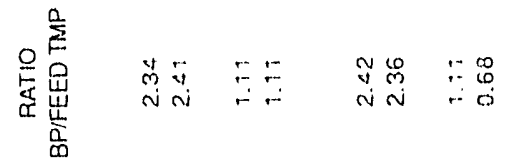

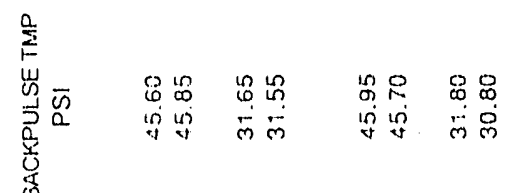

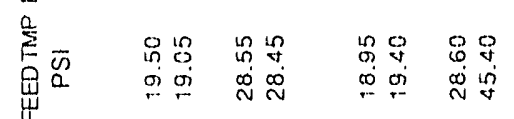

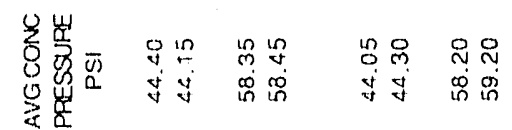

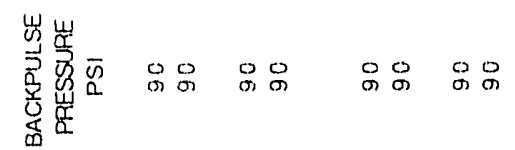
等

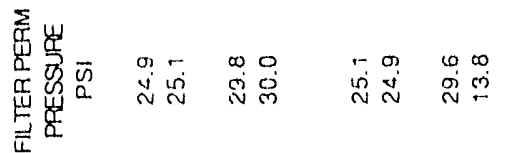

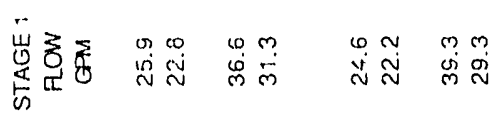

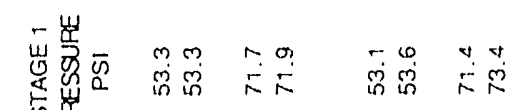
的若

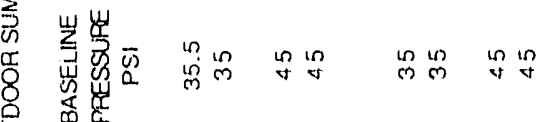

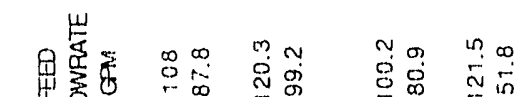
स्प 总焉 


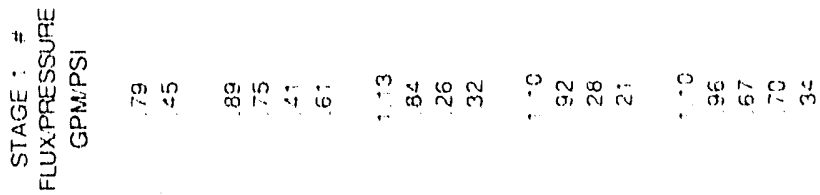

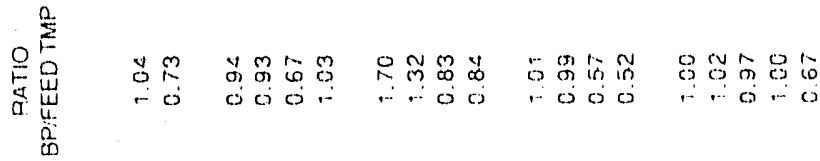
亭 岁

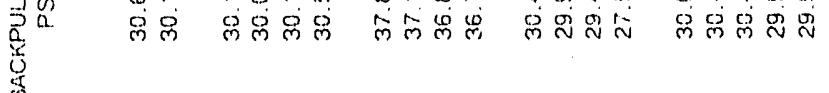

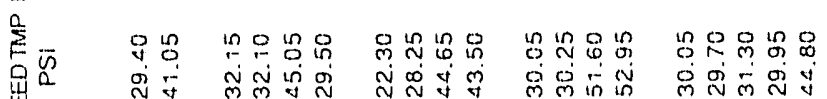

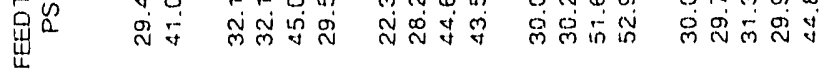

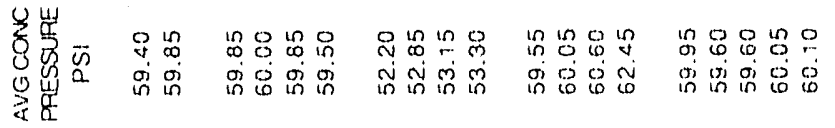

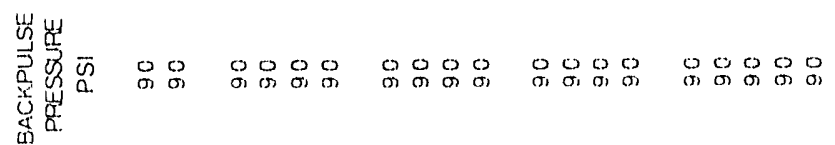

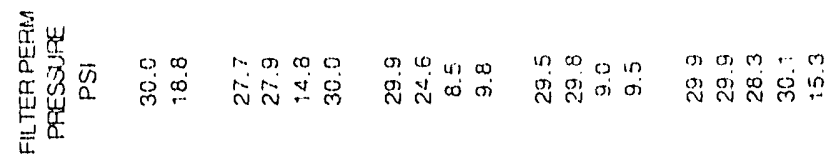

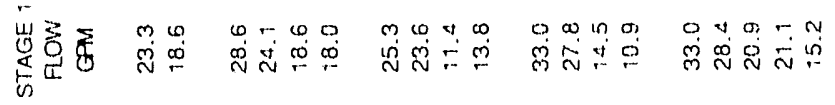

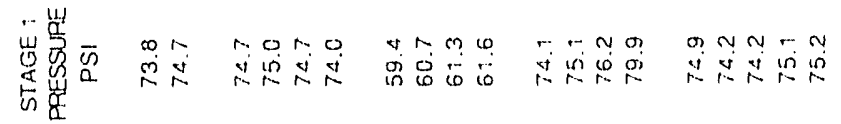

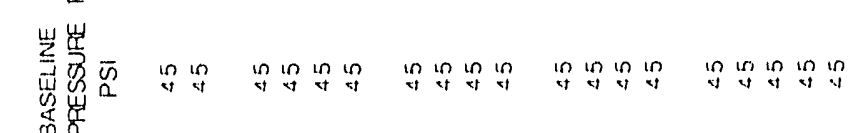

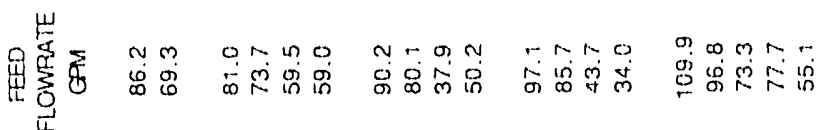

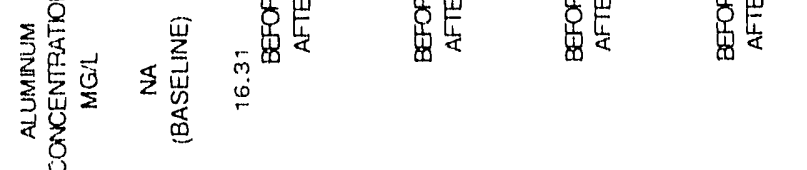

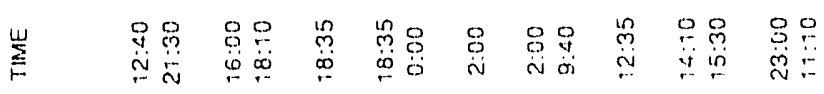

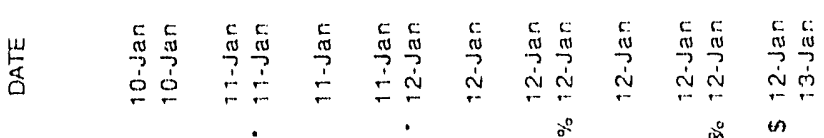

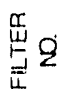

$$
\begin{aligned}
& \text { a }
\end{aligned}
$$$$
\text { m }
$$

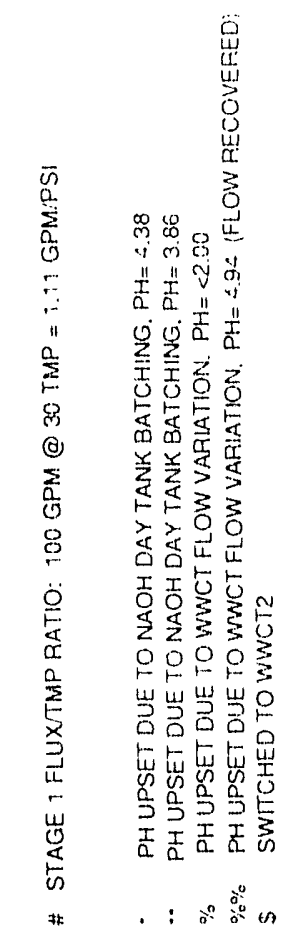


年

:

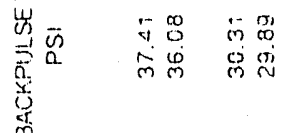

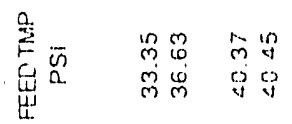

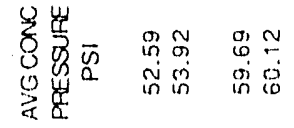

峞蓆

过

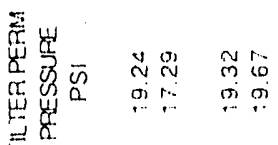

4.

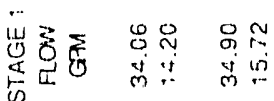

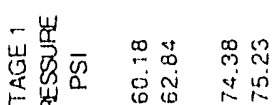

的崖

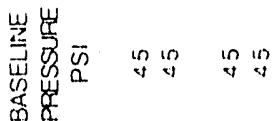

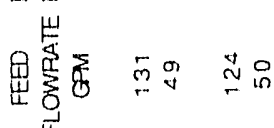

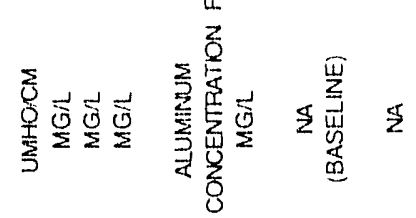

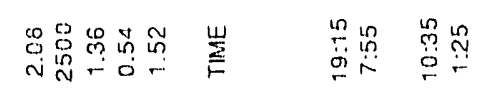

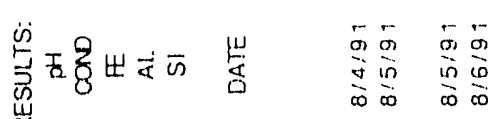

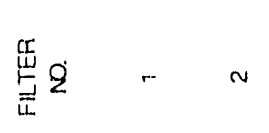

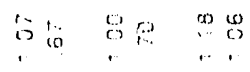

\begin{tabular}{llll}
0 & 0 & 0 & 0 \\
\hdashline 0 & 0 & 0 & $\because$ \\
\hdashline & 0 & 0
\end{tabular}

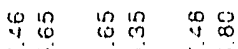

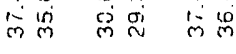

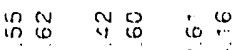

लि लू लि

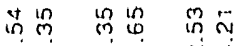

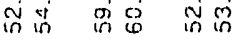

年品

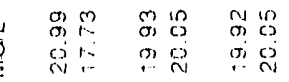

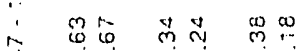

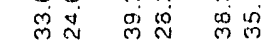

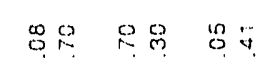

कृ 9000

in $y$ in

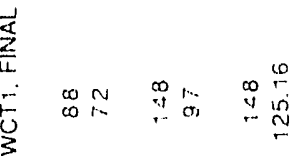

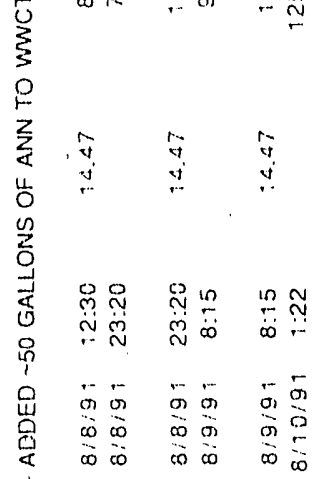

吾

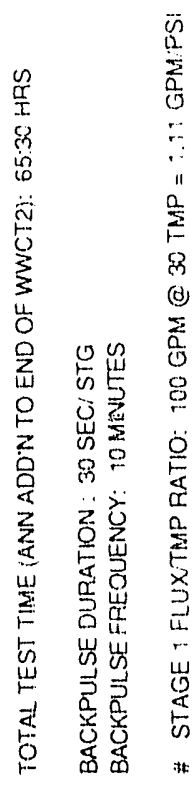




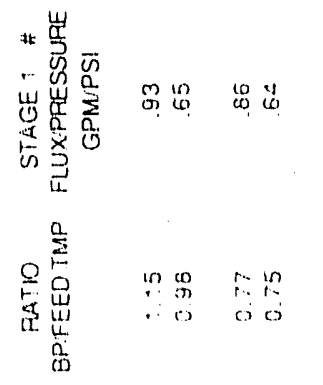

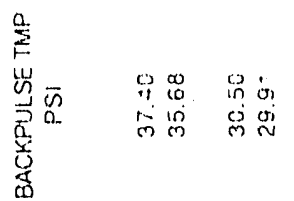

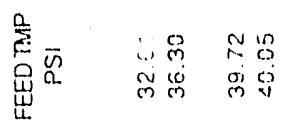

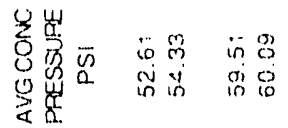

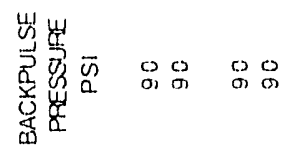

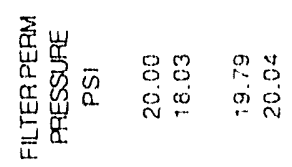

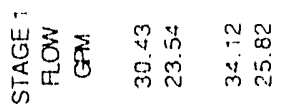

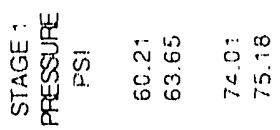

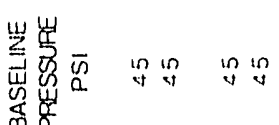

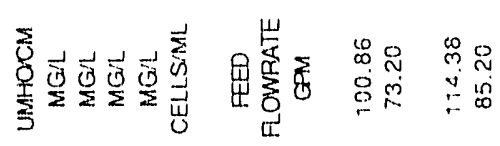

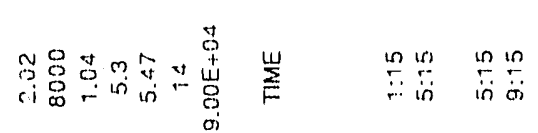

is did

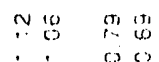

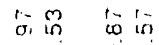

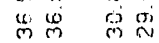

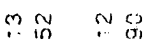

ले ले ल्ल

य) 40

究贷 in

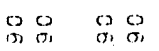

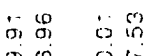

oi

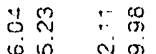

in $\stackrel{n}{\sim} \stackrel{m}{\sim}$

$\begin{array}{llll}M & 0 \\ 0 & 0 & 0 \\ 0 & 0 & 0 \\ 0 & 0 & 0\end{array}$

ถูำ

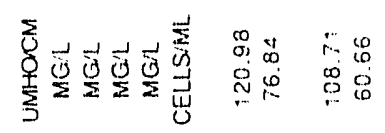

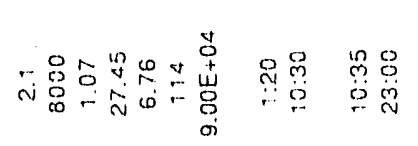

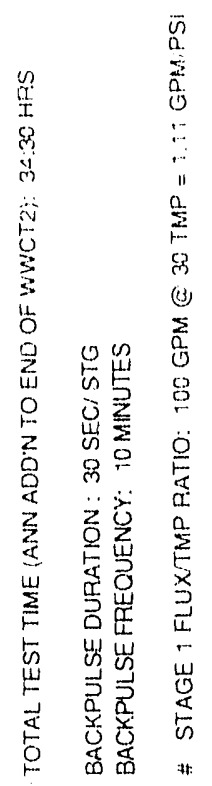




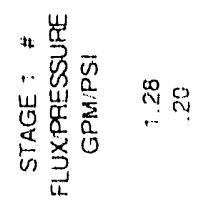

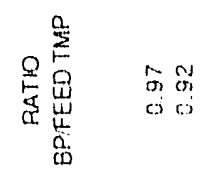

$\left(\begin{array}{ccc}1 \\ 01\end{array}\right)$

a. 0

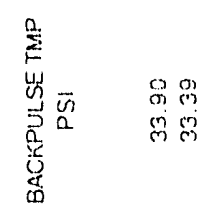

果哭

त)

ल लㅏ

लु ल ल

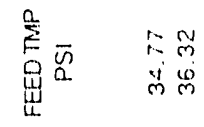

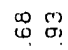

初悹

总哭

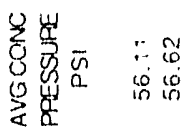

in
in
in
in
in

용

is

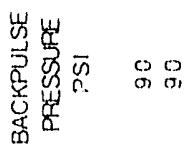

옹요

용요

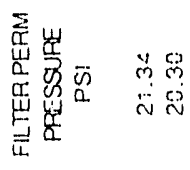

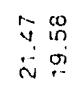

(1)

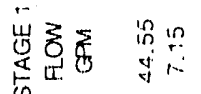

贻

(i)

(1)

कi लं

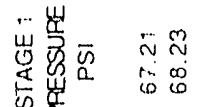

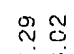

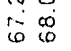

ตำ

崖崖政

\begin{tabular}{l}
0.0 \\
$:$ \\
0 \\
0 \\
0 \\
0 \\
0 \\
\hline
\end{tabular}

कि

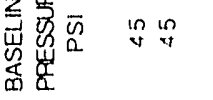

$\ln 8$

ํํㄴ

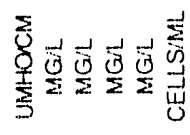

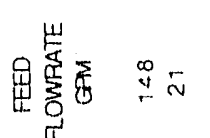

5
$\vdots$
$\vdots$
0
0
0
0

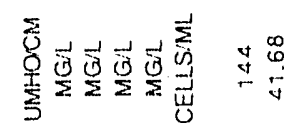

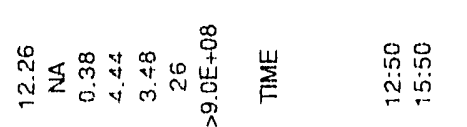

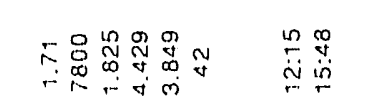

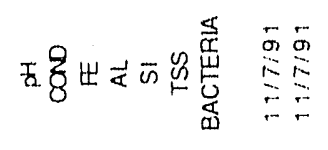

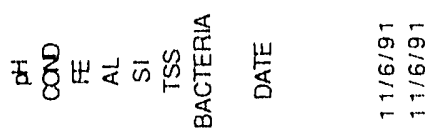

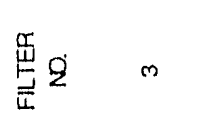

$m$

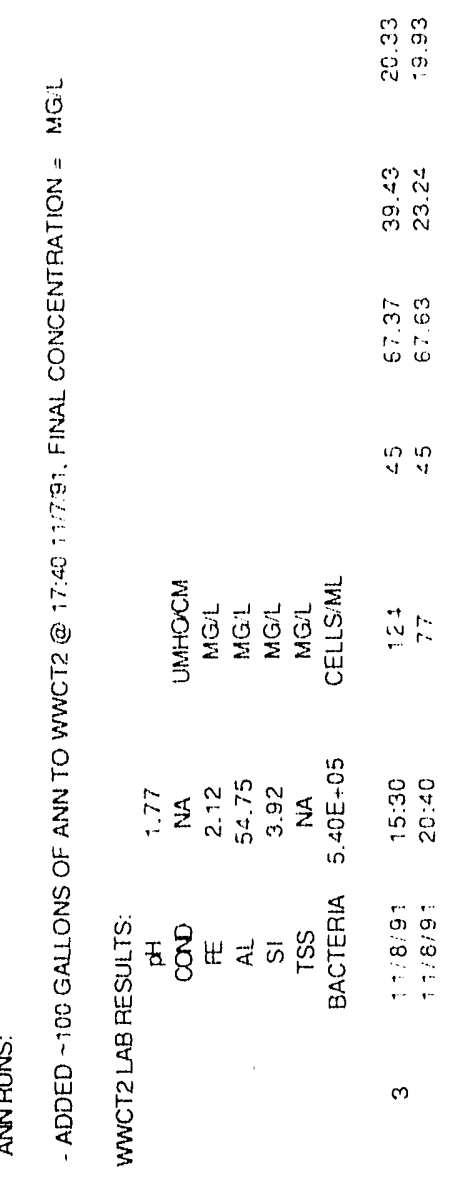




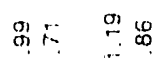

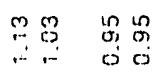

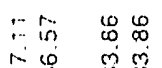

ल लिल

कृ

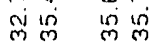

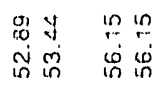

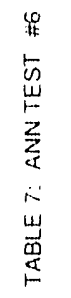

品品究品

ำ

灾灾完灾

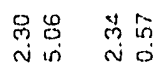

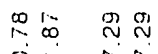

它苗

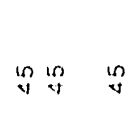

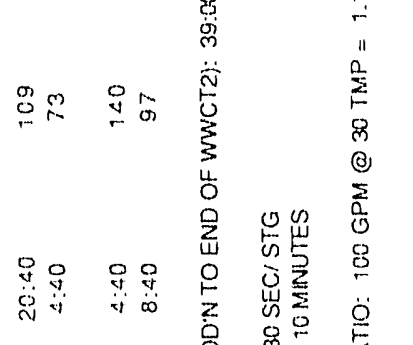

家

WSRC-RP $-92-115$ 


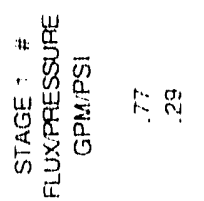

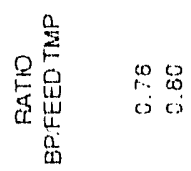

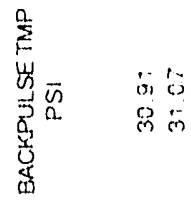

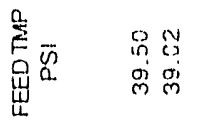

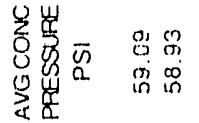

留

菒

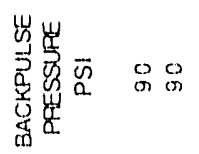

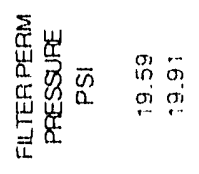

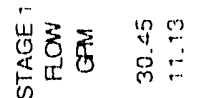

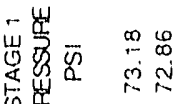

要

崖宸可

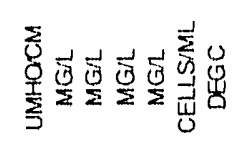

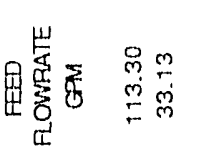

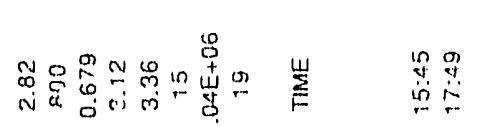

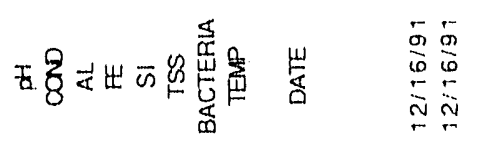

恶主 in

9
0
0

in

查

a.

लू

ชุ ญू

in

$\begin{array}{ll}0 & 0 \\ 0 & 0\end{array}$

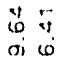

in

in 4

is

$\ln _{x \rightarrow 1} \ln _{4}$

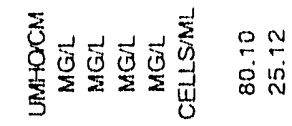

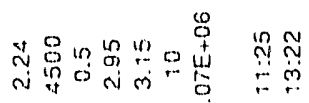

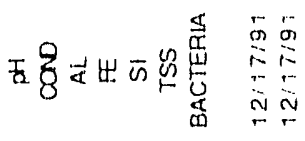

N

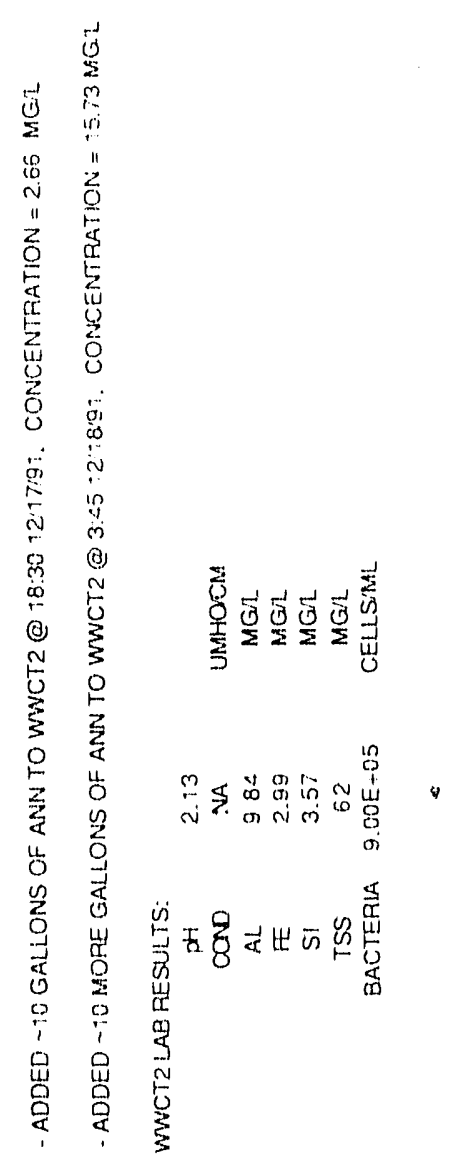


苾藏

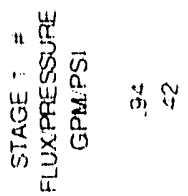

$n$
$\therefore$
0
0

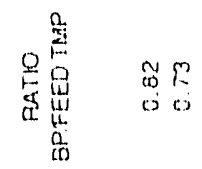

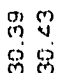

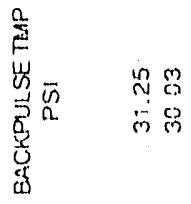

다에

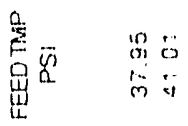

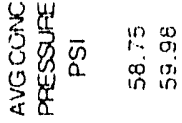

वे

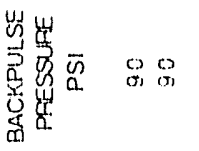

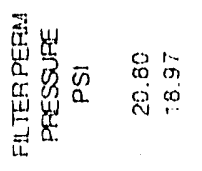

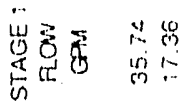

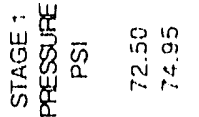

岂湈的 in

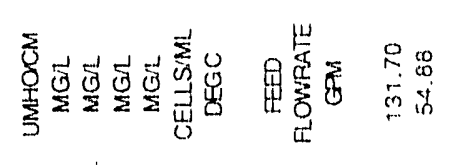

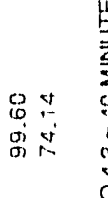

然

岁

$\ln _{y} \underset{y}{\ln }$

品

吕

突

뭉

촌

ㅊำ

$\sim$

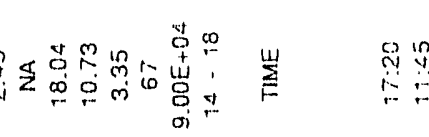

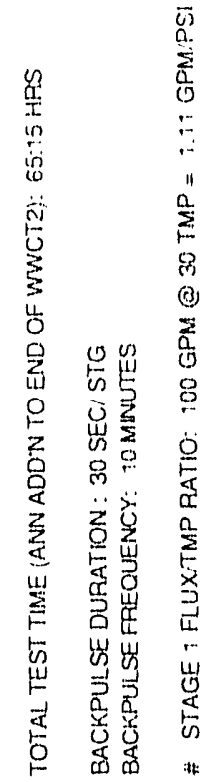



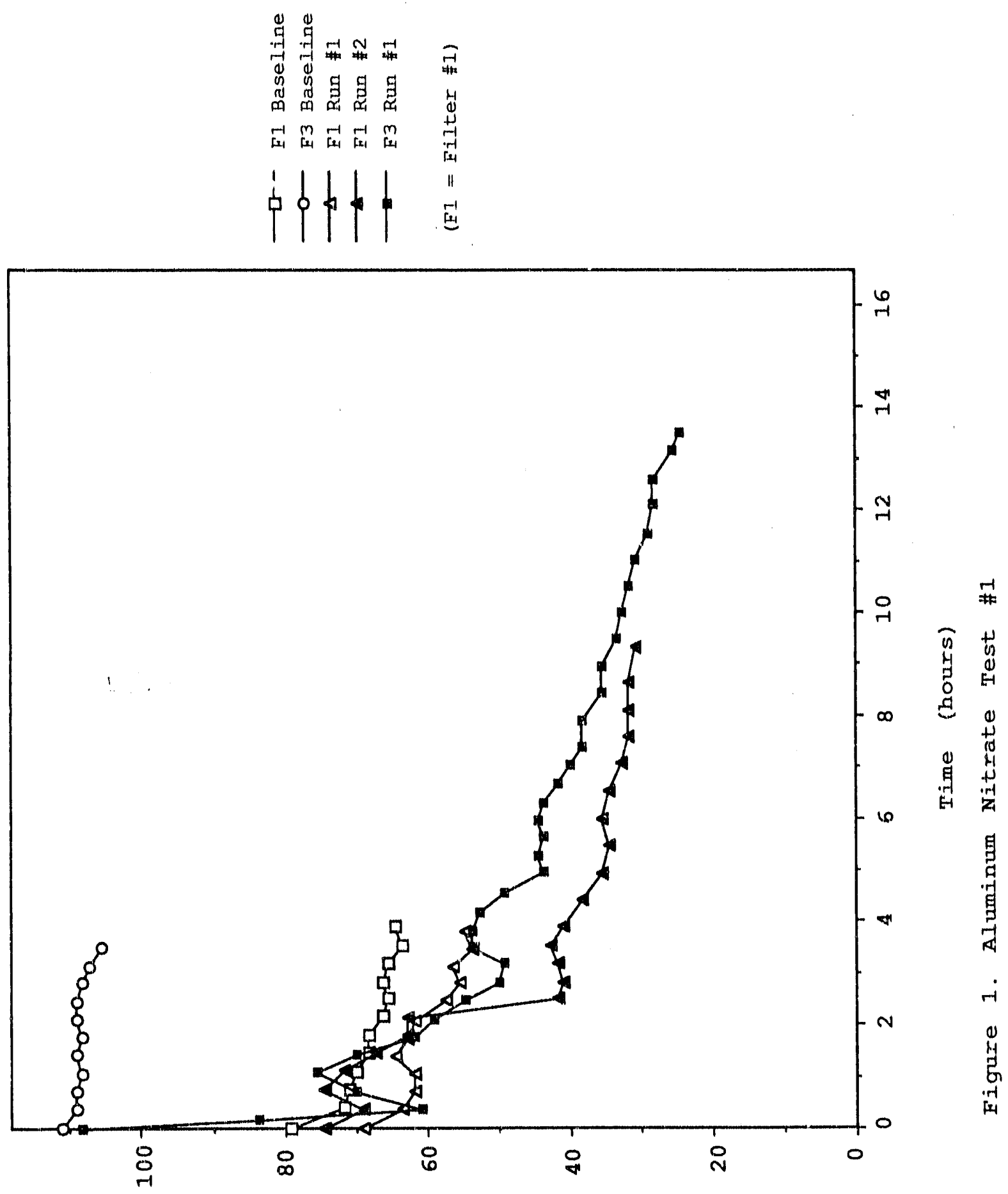

(Waפ) อ7ey mota pozetnoted 

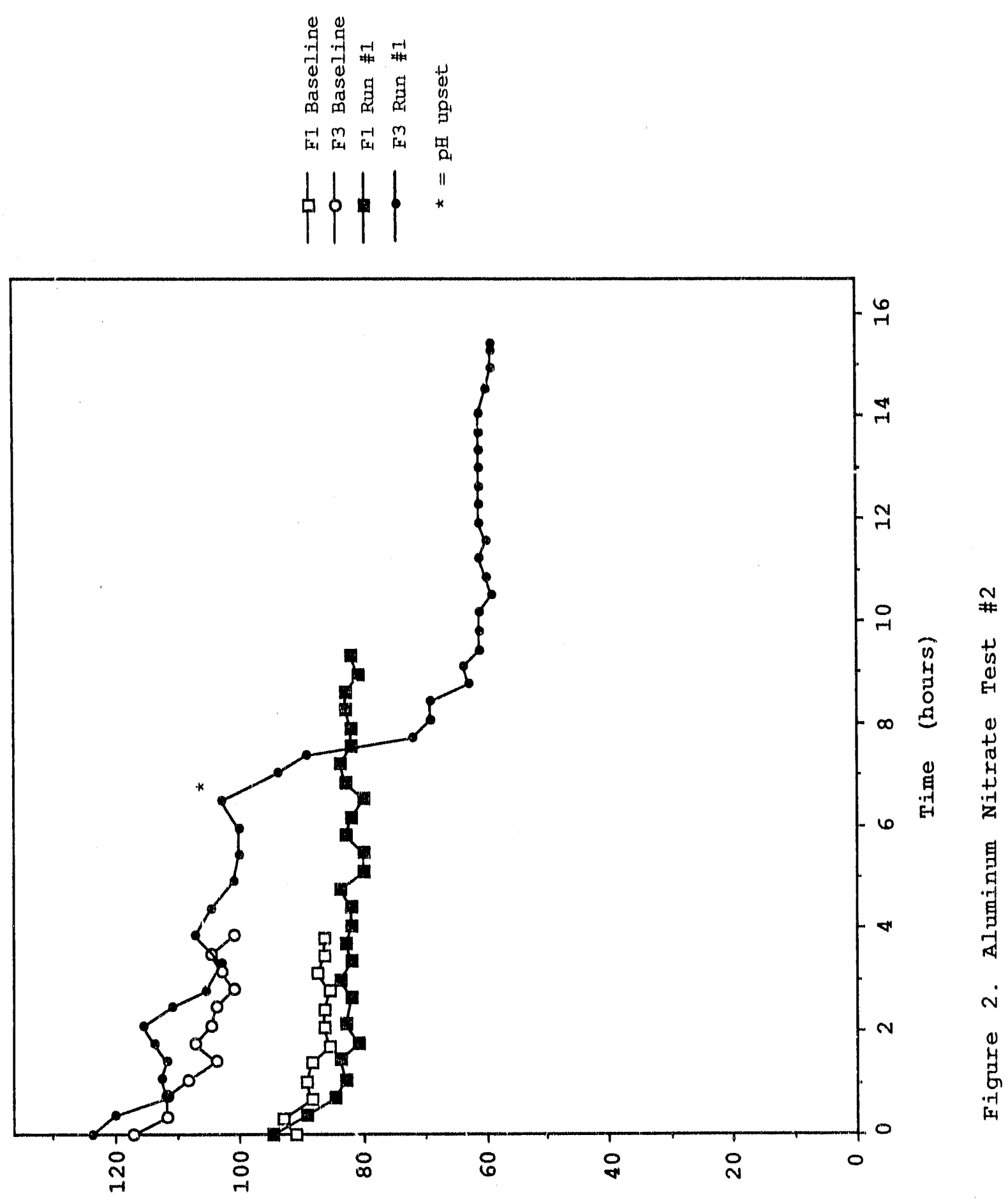

(Wवפ) өาey Mota po78tnoteo 

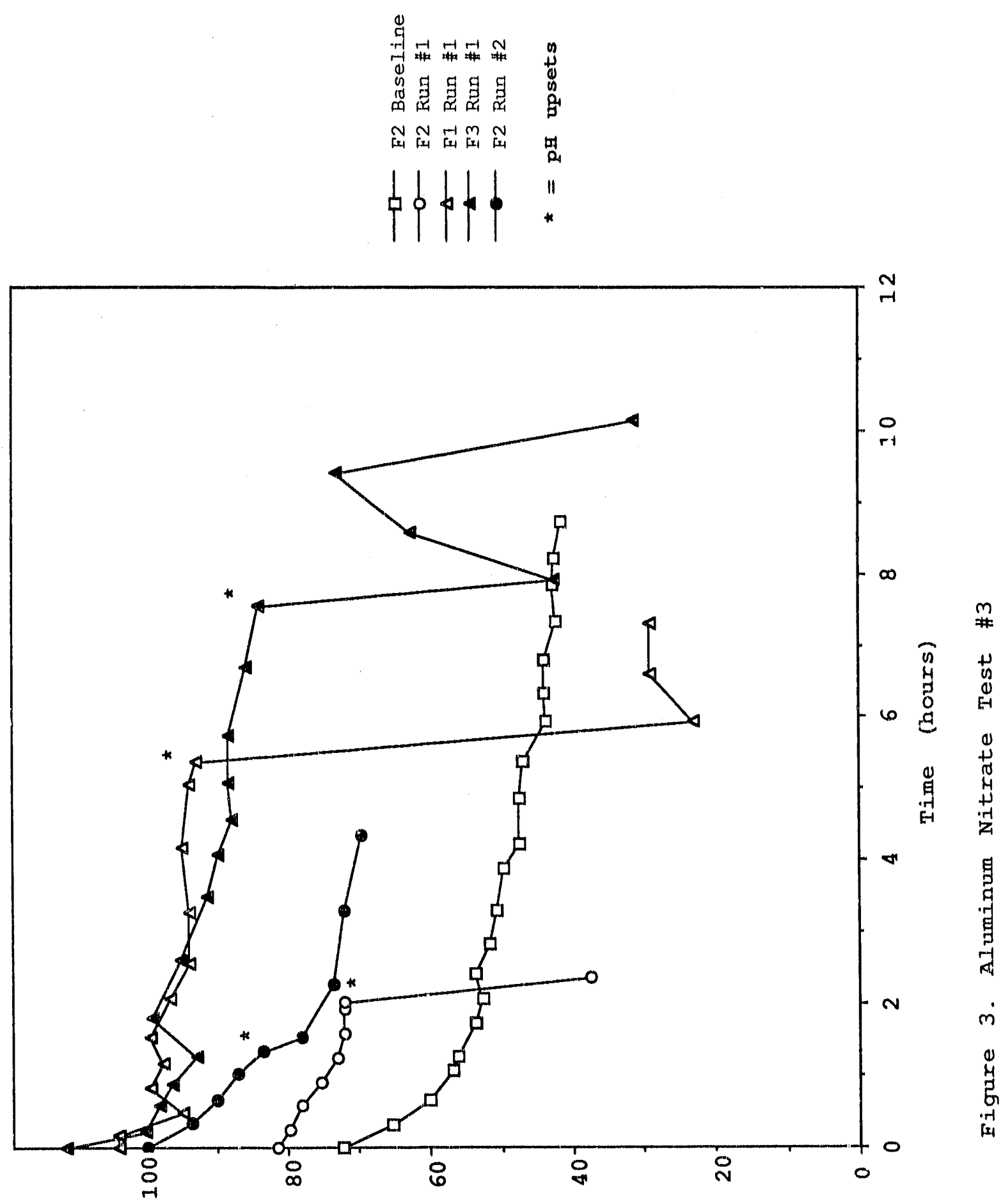

(Wdo) ө7ed Mota peqetnoteo 

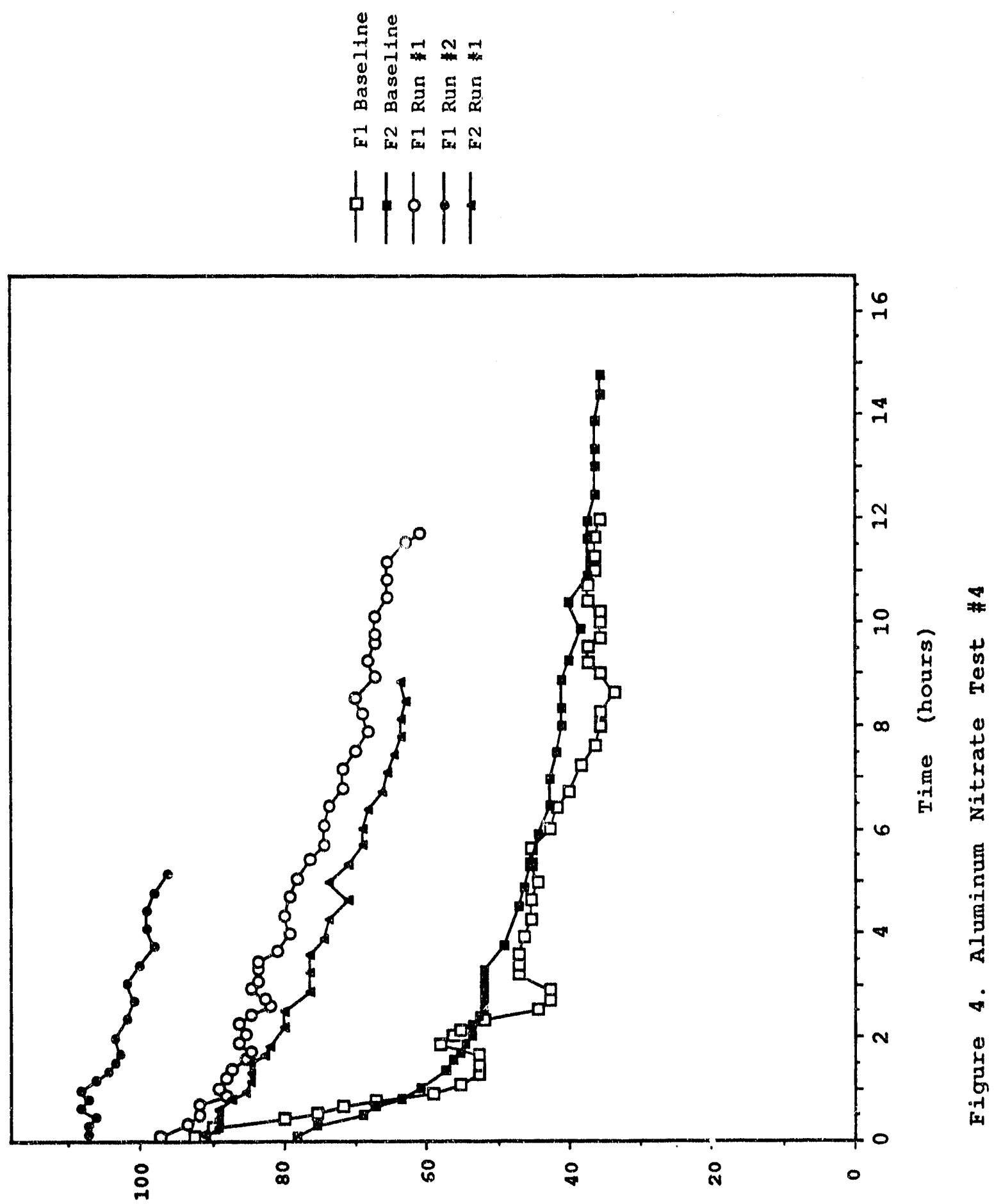

(WaD) อ7еप MOTI pozeTnoted 

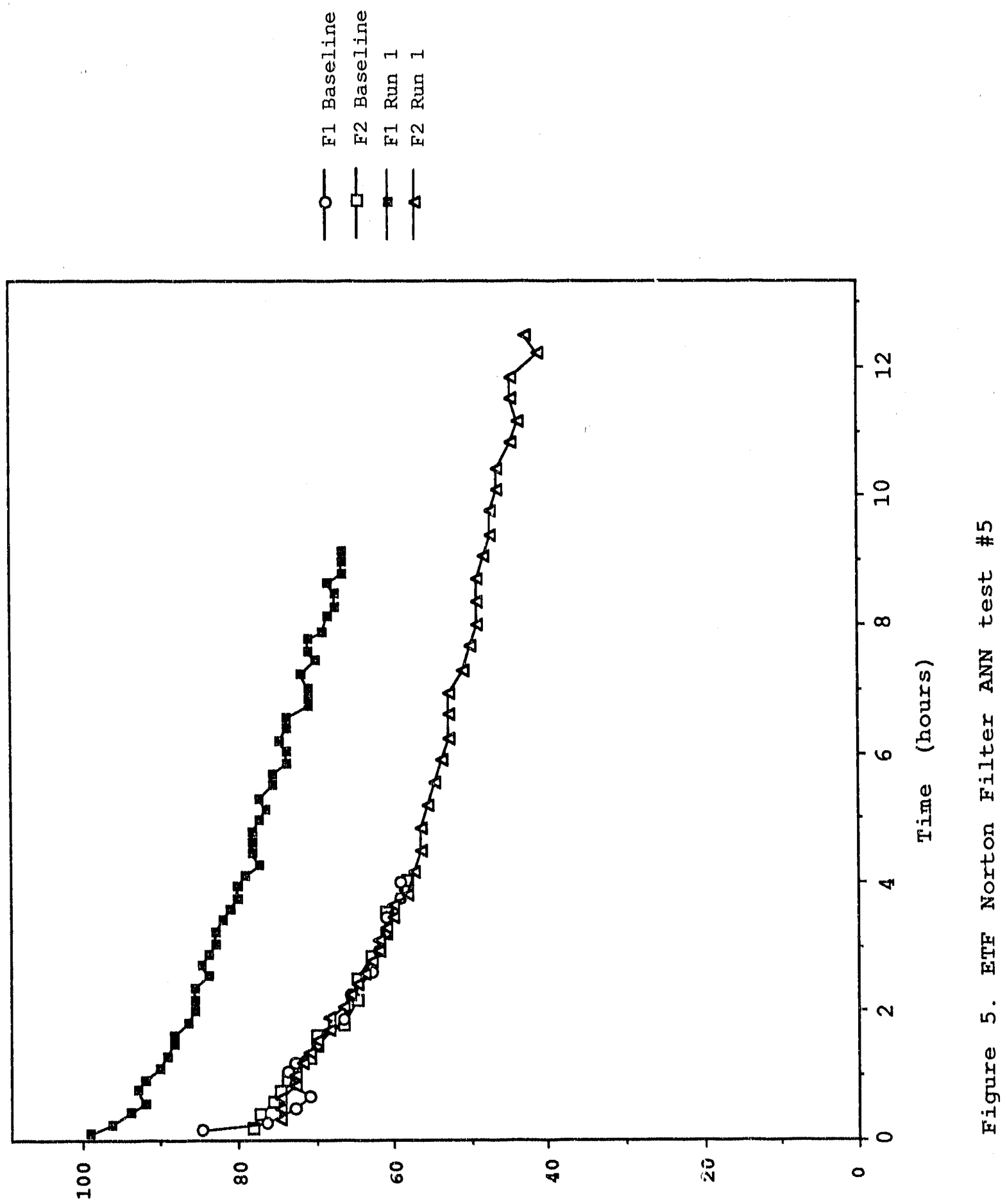

(Waפ) ө7eq Mota pozetnoted 

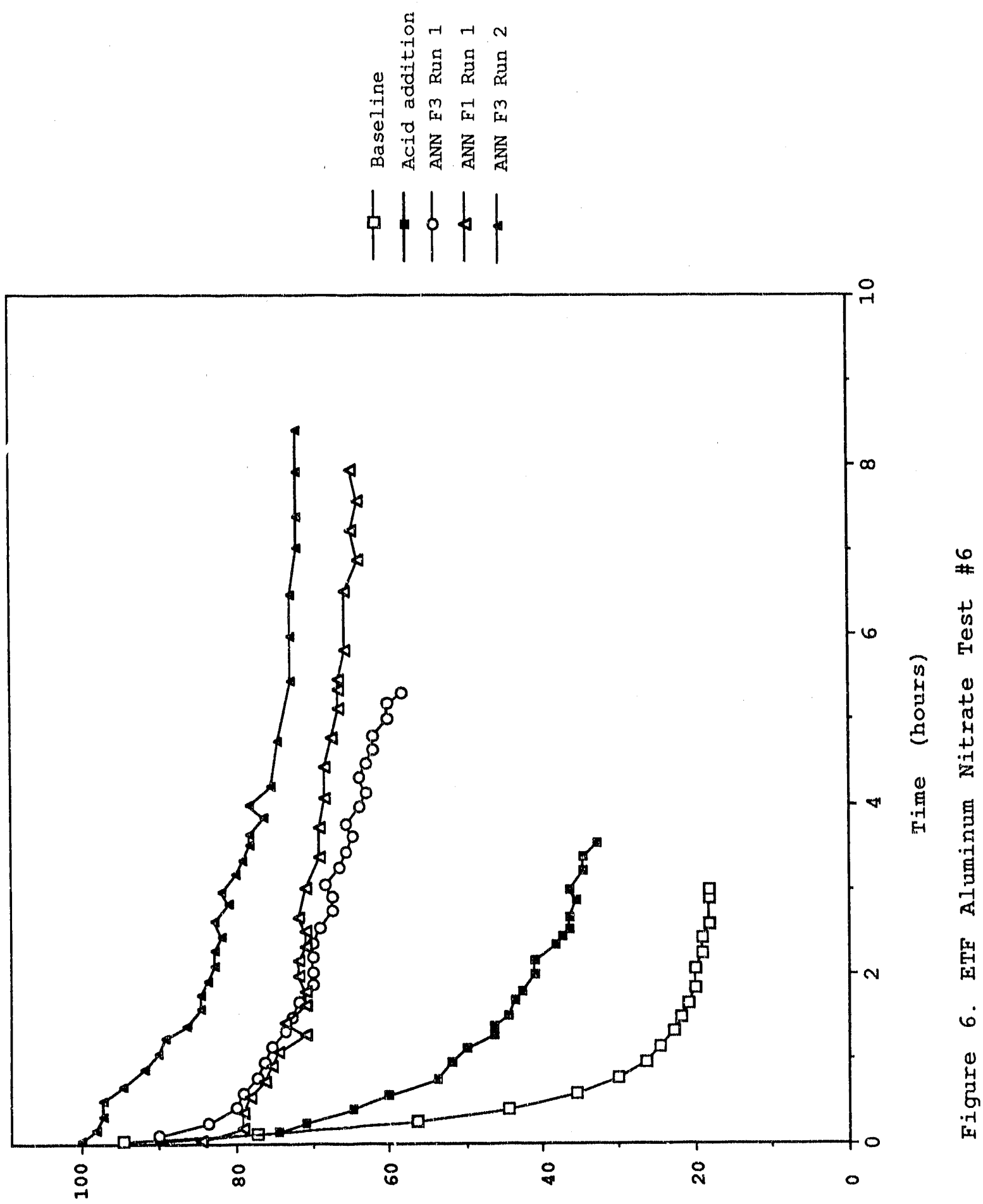

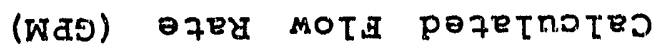



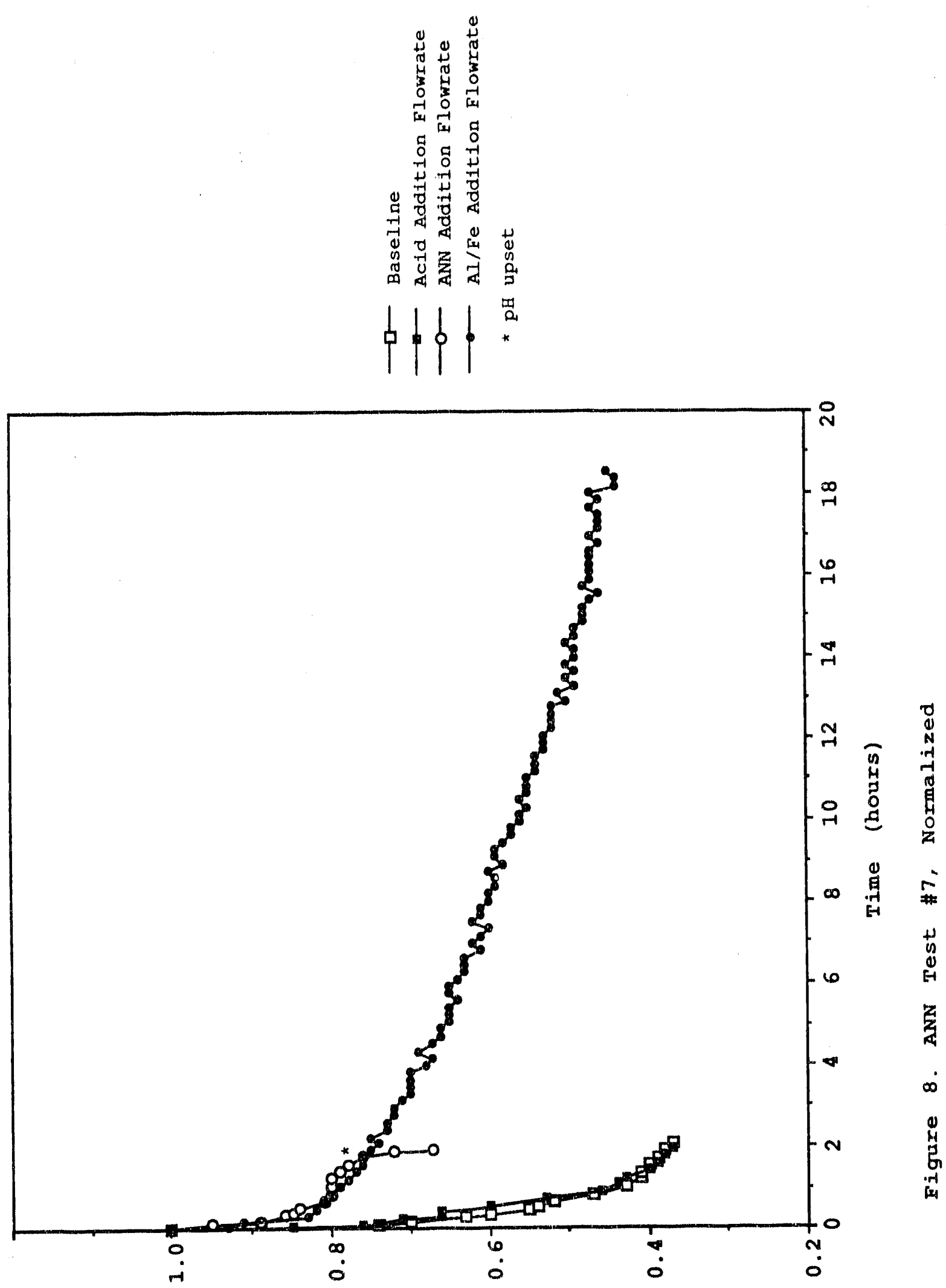

(Of/f) ofexmota peztтвmxoN 

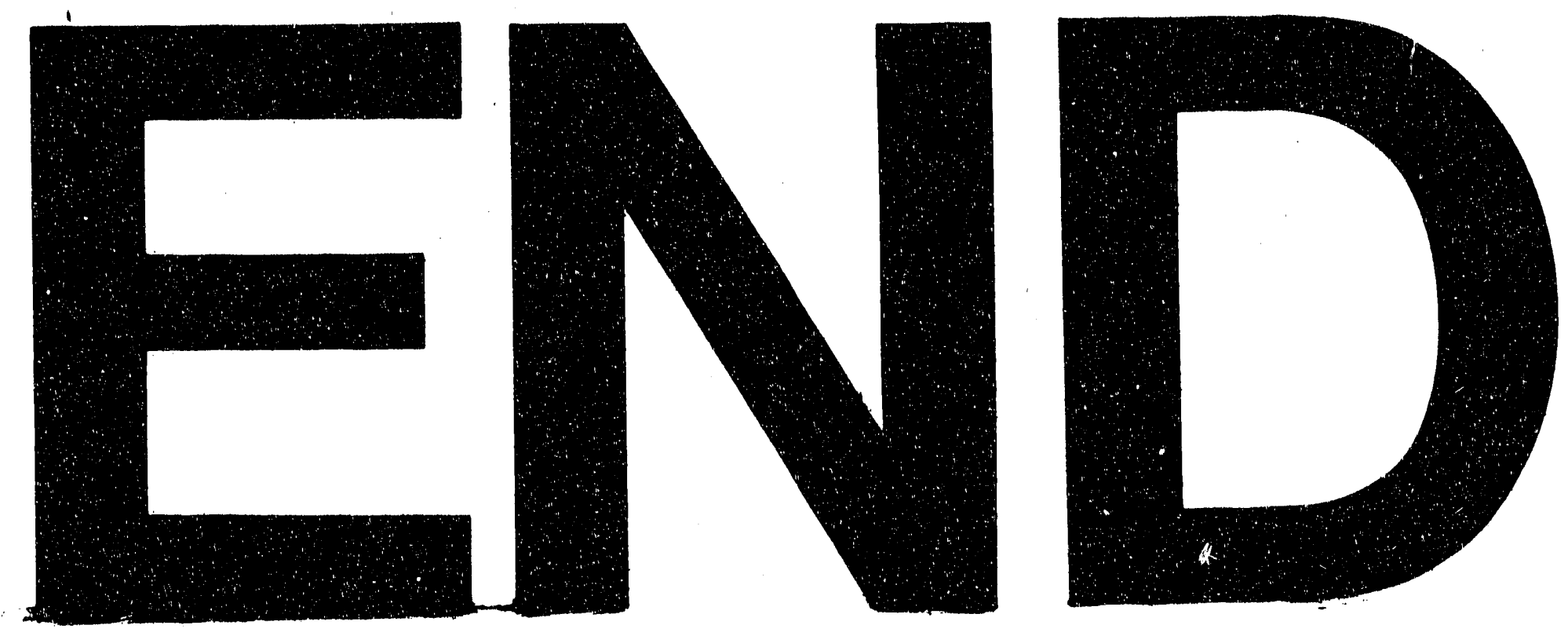

(1)
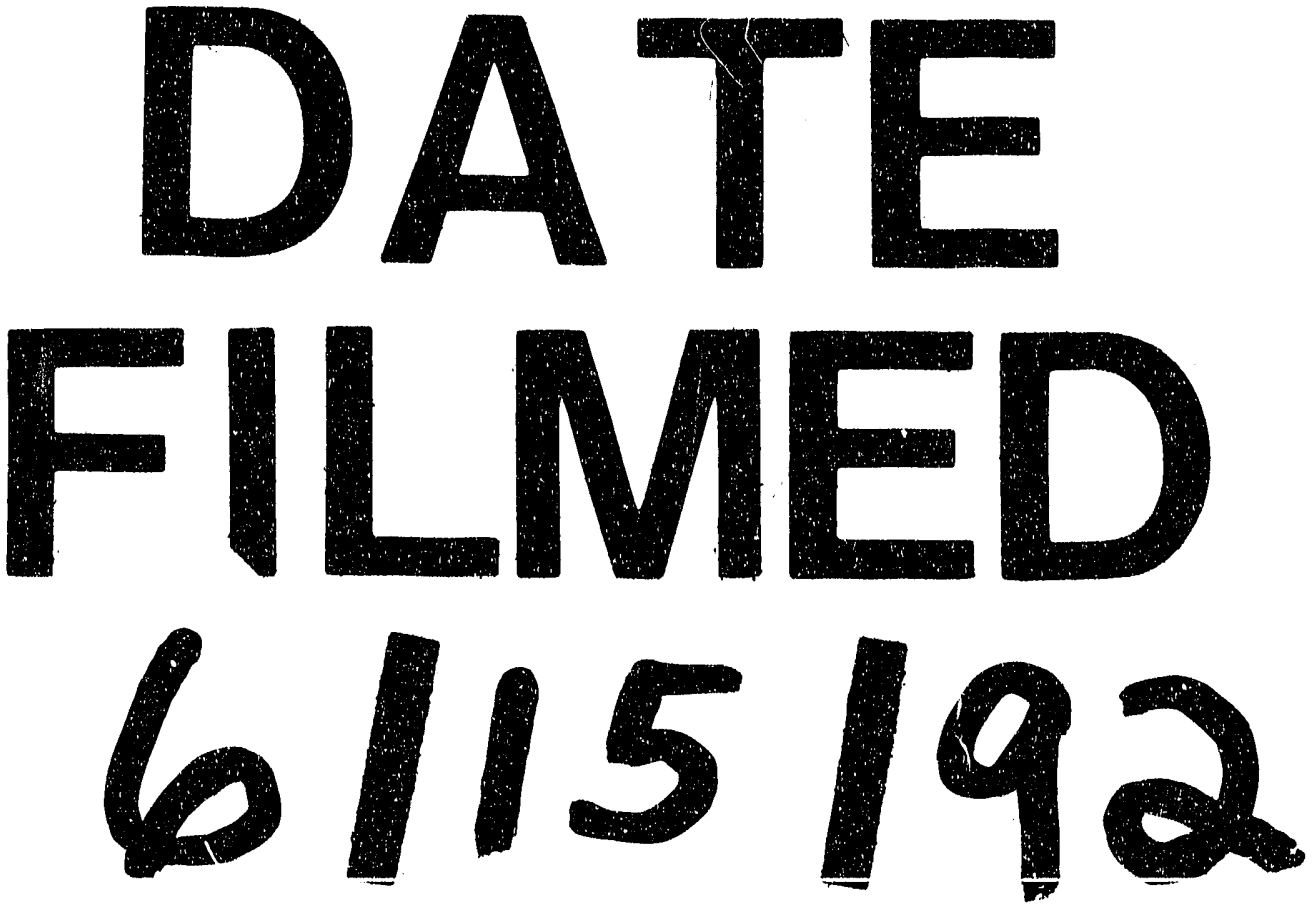
